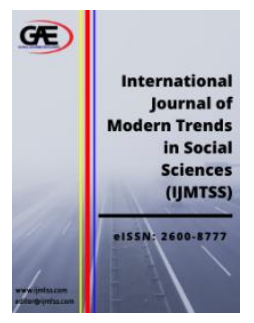

International Journal of Modern Trends in Social Sciences (IJMTSS)

Journal Website: http://ijmtss.com/ eISSN: 2600-8777

\title{
CORPORATE SOCIAL RESPONSIBILITY PROGRAMS OF PHILIPPINE MINING COMPANIES AS PERCEIVED BY HOST COMMUNITIES: AN EMPIRICAL RESEARCH
}

\author{
Jackie Lou O. Raborar ${ }^{1}$, Elizabeth O. Recio ${ }^{2}$
}

1 Ph.D. student, Commerce, The Graduate School, University of Santo Tomas, Manila, Philippines.

Email: jackielou.raborar.gs@ust.edu.ph

2 Professorial Lecturer, The Graduate School, University of Santo Tomas, Manila, Philippines.

Email: EO_recio@hotmail.com

\begin{abstract}
Article Info:
Article history:

Received date:.05.01.2020

Revised date: 17.02 .2020

Accepted date: 18.02.2020

Published date: 15.03 .2020

To cite this document:

Raborar, J. L. O., \& Recio, E. O. (2020). Corporate Social Responsibility Programs of Philippine Mining Companies as Perceived by Host Communities: An Empirical Research. International Journal of Modern Trends in Social Sciences, 3 (11), 80-91.
\end{abstract}

DOI: $10.35631 / \mathrm{IJMTSS} .311006$.

\begin{abstract}
:
Mining is a short-term and temporary operation, and it depends on how much of the mineral resources are to be extracted in a specific location. The Philippine Mining Act of 1995 allows for local and foreign granting of mining contracts that enable them to explore, develop, and utilize mineral resources. While mining is perceived to be temporary due to the fact that its operations have a specific end, its operations can contribute significantly to the sustainable development of the host communities once its objectives are aligned to promoting the development of the affected communities. This study quantitatively investigated the corporate social responsibility programs of mining companies based on the perception of the host communities using survey questionnaires distributed to 376 individuals. The results revealed that there are social issues raised with regard to the mining projects. However, they strongly agreed that "the community benefitted from the infrastructure $\mathrm{P} / \mathrm{P} / \mathrm{AsP} / \mathrm{P} / \mathrm{A}$ implemented from the SDMP of the Company (Mean $=1.36, \mathrm{SD}$ $=.572)$. Generally, the respondents agreed the SDMP were implemented accordingly.
\end{abstract}

Keywords:

Corporate Social Responsibility, Host Communities, Mining, Sustainability

\section{Introduction}

Mining is a short-term and temporary operation, and it depends on how much of the mineral resources are to be extracted in a specific location. The Philippine Mining Act of 1995 allows for local and foreign granting of mining contracts that enables them to explore, develop, and utilize mineral resources. 
Thus, the national government has significantly increased its focused on the mining industry to enhance economic growth here in the Philippines, one of the most mineral-rich countries in the world. A total of $\$ 2.32 \mathrm{~B}$ exports of mineral and taxes of approximately Php22.69B generated and contributed as of the CY 2017, (MGB mining facts and figures) the mining industry in the Philippines continue to meet all the needs of the present generation (MGB, 2018).

However, the said industry is facing its biggest problem when it comes to adverse environmental and local community impacts. Mining is not and cannot be a sustainable activity, because its operation has a specific end. However, according to The International Council on Mining and Metals (ICCM, 2012) mining can significantly contribute to sustainable development if they can align their objectives to the values of the society in promoting socioeconomic growth and development of the impacted communities (Pimentel, Gonzalez, \& Barbosa, 2016).

\section{Statement of the Problem}

The study aimed to assess the Social Development and Management Programs for Communities of the Top 5 Mining Companies in Luzon”. Specifically, the following questions were addressed:

1. What is the perception of the respondents on the sustainability of the Social Development and Management Programs of the mining companies in terms of?

1.1 Stakeholder Groups Relationship;

1.2 Company Financial and Management Capacity; and

1.3 Compliance with the Legal Requirements?

2. Is there a significant relationship between the implementation of the SDMP and the impact on the different aspect of socio-economic?

3. Does the implementation of the SDMP affect the different aspect of socio-economic in the Barangay?

\section{Literature Review}

\section{The Philippine Mining Industry}

In the Philippines, there is the adoption of the EITI or the Philippine- Extractive Industries Transparency Initiative (PH-EITI) as mandated to all mining companies, to promote transparency in their financial undertakings. The Extractive Industries Transparency Initiative (EITI) is a global standard of transparency that requires oil, gas, and mining companies to publish all financial transactions with the government (taxes, royalty, etc.), and the government will announce what they collect from these mining companies in the report (PH-EITI, 2014). The mandated reporting in the Philippines will benefit the government, companies and citizens. There are continuous improvements for this; it was suggested to also include social and economic contributions to ensure that such contributions have sustainable impact (PH-EITI, 2014). The Philippines was entered as a candidate country by the EITI board on May 22, 2013.

Many countries incorporate community development in their policies and laws, in order to ensure the reversal of the negative impact of mining activities (Dupuy, et al; 2014). The mining industry in some countries is the major source of their revenue through foreign exchange (Dupuy, 2014; ICMM, et al., 2011). Previous studies mentioned that global norms, especially in the mining industry, obviously consider the higher regulatory standards especially if it's coming from big countries. Investors are most likely to invest if they see that there are certain 
qualities and good behaviors to prove that their investments are secured (Greenhill, et al., 2009). The only challenge to the countries that adopted community development into their mining laws is the impact of the implementation (Dupuy, 2014).

\section{Community Development in the Mining Industry}

A few years back, the World Bank oil, gas, and mining units were brought to analyze community development agreement (CDA) within the mining industry as a tool for more sustainable and fair benefits, to improve the cooperation and dialogue, manage anticipation of involved parties, and later increase the benefits of the poor while helping to obtain "social license to operate" for governments and industry (Mining Community Development Workbook, 2012).

The World Bank Group (WBG) continues to coordinate with stakeholders to create a more sensible approach that can be adopted by the mining companies, government, and other stakeholders. Examples of this coordination are Equator Principles (lending principles) and a "Community Development Toolkit" (jointly developed and published by the World Bank Group and the International Council on Mining and Metals). There are many tools that seek the summons of raising local community benefits. Community Development Agreements (CDA) between companies and affected communities have an imperative part role in meeting the current needs of the stakeholders, nonetheless different approaches to community development agreement comes with varying results (Mining Community Development Agreement Source Book, 2012).

\section{Corporate Social Responsibility in the Mining Industry}

Discretionary social expenditures are the initiatives of the mining companies to go beyond compliance, and it should be based on the CSR standards and guidelines. However, although there are such standards, these voluntary guidelines do not secure the best practices and compliance scenarios since there are no sanctions if they will not continue the activities.

\section{CSR Practices of Selected Mining Companies in the Philippines}

\section{Holcim Mining and Development Corporation}

Their CSR programs provide education initiative, like Foster a Child's Education (FACE), which has been recognized and awarded with sustainable business practices and show leadership and commitment to ethical values, respect for people, community participation and protection of the environment. Holcim Philippines' Communication and Corporate Affairs implements FACE in partnership with stakeholders also in coordination with Department of Social Welfare and Development, and the Department of Education. According to Holcim Mining, it is guided by the belief that "it takes a village to raise a child," thus, the partnerships with and engagement of the school administration, parents, community leaders and other stakeholders (Holcim Mining and Development Corporation, https://www.holcim.ph/news/latestreleases/latestrelease/article/holcim-philippines-educationprogram-wins-regional-csr-award).

\section{Republic Cement and Building Materials Incorporated}

Their CSR programs provide assistance to fight against malnutrition, give aids to evacuees by conducting relief operations, brigada eskwela, my tree for my pen and paper to replace lost trees, Kusina ng Kalinga in Batangas, electrification in Alanga, Resilient house and affordable housing, Alternate fuel, Reforestation and Tubbatha Ranger Station (Republic Cement and 
Building Material Incorporated, http://www.republiccement.com/our-advocacies/corporatesocial-responsibility).

\section{OceanaGold Phils., Inc.}

They are focused on programs that improve local education opportunities, health services, protect and respect culture of the local communities, infrastructures, micro business support and jobs. OceanaGold is committed to sustainable development (OceanaGold Phils., Inc., http://www.oceanagold.com/sustainability/).

\section{Philex Mining Corporation}

When it comes to CSR programs, Philex is one of the top best mining companies. Their advocacies for the environmental and social projects are embodied to the principle of Social Development and Management Program (SDMP), such as health services, education, livelihood programs, public infrastructure, and some foundations (Philex Mining Corporation http://www.philexmining.com.ph/2014/04/07/philex-mining-named-one-of-phs-best-in-csradvocacy/).

Above are some of the CSR practices of mining companies in the Philippines. The experience of the number of mining companies in corporate social responsibility can be a model to other mining companies to also adhere to the sustainable development practices. Mining companies should realize the significance of these programs and accept the need to communicate the impact to business itself and to the communities to avoid conflicts and issues (DENR-MGB, government publication).

\section{Social Impact Assessment and Sustainable Development}

It is important to create indicators or adopt them from different frameworks to monitor the mining industry's adherence to the sustainable development guidelines. With regards to indicators, it should be the agreement between the stakeholders and the mining companies in assessing sustainable compliance (Zvarivadza, 2018). Some other indicators suggested by the Global Development Research Center (GDRC, 2017) such as the Equator Principles (EP), Human development index (HDI), Environmental Sustainability Index (ESI), Pilot Environment Performance Index (EPI), and Ecological footprint (Zvarivadza, 2018).

The Social Impact Assessment is a process of analyzing the impact of intervention on the social aspects of the human environment. Today there is a common understanding of "social impact" - what it is or how to measure it. Currently, measures of impact depend from funder to funder, and organization to organization. The more appropriate measurement tools integrate organizational and process metrics with quantifiable outcome data, but in the absence of a common measure (like shareholder value) investors and grant makers are making it up as they go along, the impact value chain and role of SIA.

The success of a social assessment depends on many factors, such as the relevance and accuracy of the data, the timeliness and effort to carry out the social survey and analysis. However, the maximum test of a quality social assessment is its impact on program design and implementation, and this depends on the specificity of recommendations for achieving various set of social development objectives (World Bank, Social impact assessment, 1998).

\section{Research Framework}

The effective implementation of SDMP would have positive effect on the standard of living of the community such as: Human Resource Development, Enterprise Development, Assistance 
to Infrastructure Development, Access to Education, Access to Health Services, and Protections to Respect of Socio-Cultural Values.

These SDMP if implemented effectively would have a positive effect on the socio economic of the community namely: Education, Health, Social and Cultural, and Economic aspect. It will be used to develop a policy model to improve the implementation of the SDMP.

$S D M P$

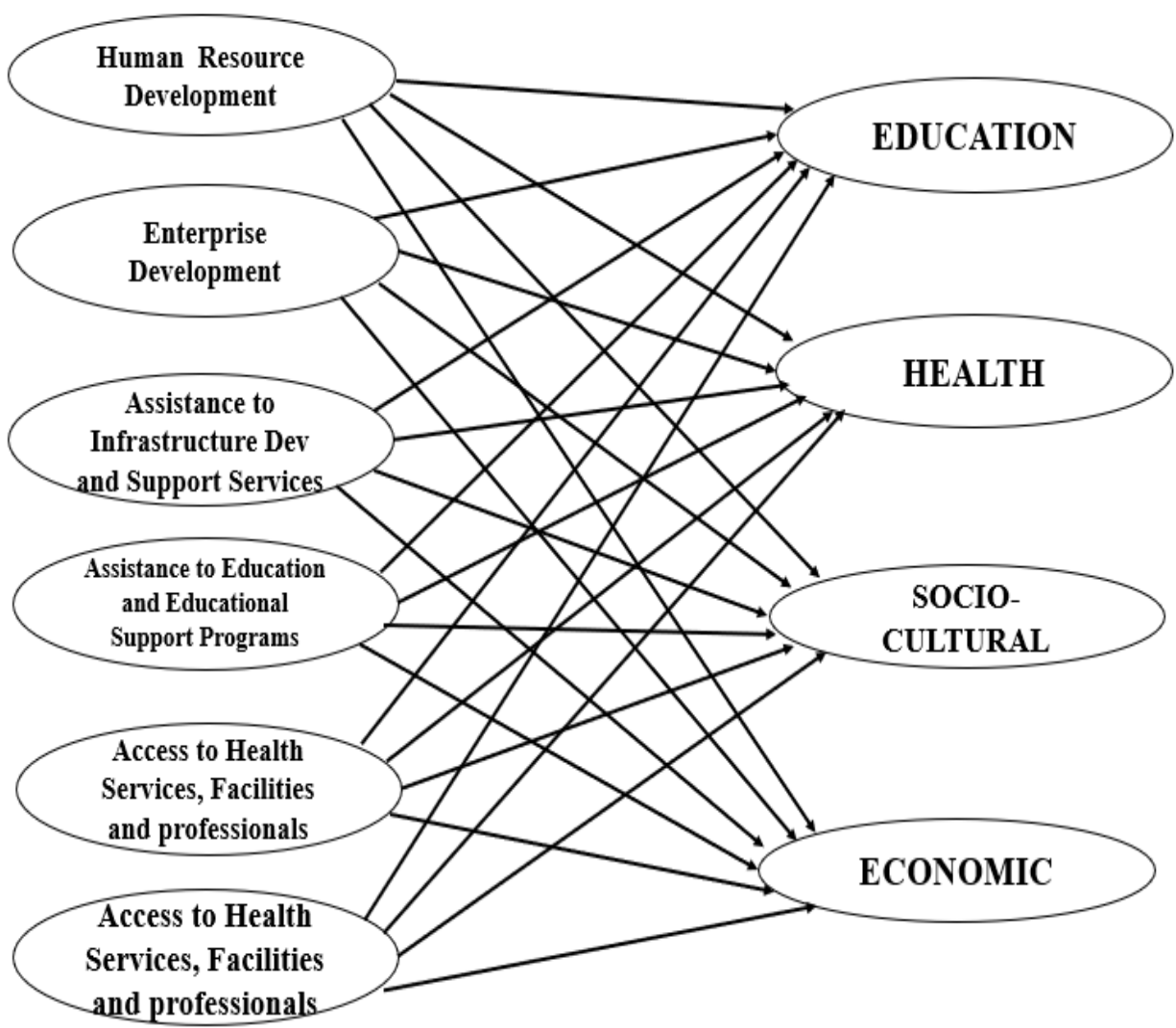

Figure 1: Framework Showing the Effect of The SDMP To the Different Aspect of Socio Economic

The conceptualized model shows the effect of the SDMP on the aspect of socio economic of the residents of Barangay. These SDMPs are Human Resource Development, Enterprise Development, Assistance to Infrastructure and Development, Access to Education and Educational Support Programs, Access to Health Services, Facilities and professionals, and Protection and Respect of Socio-Cultural Values

\section{Research Methodology}

Both descriptive and inferential statistical analyses were used. Descriptive analysis was used for describing the profile and level agreement of the respondents on the Social Development and Management Programs for Communities of the Top 5 Mining Companies in Luzon.

Frequency and percentage were used to describe the characteristics of the respondents. Mean and standard deviation were used to define the level of agreement of the respondents on the Likert scale items namely: 
The mean was interpreted as follows:

\begin{tabular}{|l|l|}
\hline Scale & Interpretation \\
\hline $1.00-1.74$ & Strongly agree (SA) \\
\hline $1.75-2.49$ & Agree(A) \\
\hline $2.50-3.24$ & Disagree (D) \\
\hline $3.25-4.00$ & Strongly disagree (SD) \\
\hline
\end{tabular}




\section{Results and Discussions}

Table 1: Summary of the Level of Agreement of the Respondents on the Implementation of the Social Development and Management Programs of the Mining Companies in terms of:

\begin{tabular}{|c|c|c|c|c|c|c|c|c|c|c|c|c|}
\hline \multirow[t]{3}{*}{ Social Development and Management Programs } & \multirow{2}{*}{\multicolumn{2}{|c|}{$\begin{array}{l}\text { CAMP } 3 \\
\mathrm{~N}=45\end{array}$}} & \multirow{2}{*}{\multicolumn{2}{|c|}{$\begin{array}{c}\text { DIDIPI0 } \\
\mathrm{N}=2 \mathrm{l}\end{array}$}} & \multirow{2}{*}{\multicolumn{2}{|c|}{$\frac{\text { MINUYAN }}{\mathrm{N}=54}$}} & \multirow{2}{*}{\multicolumn{2}{|c|}{$\begin{array}{l}\text { SAN R0QUE } \\
\mathrm{N}=212\end{array}$}} & \multirow{2}{*}{\multicolumn{2}{|c|}{$\frac{\text { MATICTIC }}{\mathrm{N}=44}$}} & \multirow{2}{*}{\multicolumn{2}{|c|}{$\begin{array}{l}\text { Overall } \\
\mathrm{N}=376\end{array}$}} \\
\hline & & & & & & & & & & & & \\
\hline & Mean & SD & Mean & SD & Mean & SD & Mean & SD & Mean & SD & Mean & SD \\
\hline \multicolumn{13}{|l|}{ Human Resources Development } \\
\hline $\begin{array}{l}\text { Implemented its P/P/As from its SDMP such as training } \\
\text { intended for members of existing local organizations. }\end{array}$ & $\begin{array}{l}1.42 \\
\text { SA }\end{array}$ & .499 & $\begin{array}{l}1.57 \\
\text { SA }\end{array}$ & .507 & $\begin{array}{l}1.78 \\
\text { SA }\end{array}$ & .816 & $\begin{array}{c}1.95 \\
\mathrm{~A}\end{array}$ & .762 & $\begin{array}{c}2.25 \\
\mathrm{~A}\end{array}$ & 1.203 & $\begin{array}{c}1.88 \\
\mathrm{~A}\end{array}$ & .825 \\
\hline $\begin{array}{l}\text { The community organizations improve out of the } \\
\text { support of the company on the SDMP. }\end{array}$ & $\begin{array}{l}1.40 \\
\mathrm{SA} \\
\end{array}$ & .495 & $\begin{array}{l}1.38 \\
\text { SA }\end{array}$ & .498 & $\begin{array}{c}1.91 \\
\mathrm{~A}\end{array}$ & .652 & $\begin{array}{c}2.02 \\
\mathrm{~A}\end{array}$ & .712 & $\begin{array}{l}1.70 \\
\mathrm{SA}\end{array}$ & .734 & $\begin{array}{c}1.86 \\
\mathrm{~A}\end{array}$ & .711 \\
\hline \multicolumn{13}{|l|}{ Enterprise Development } \\
\hline $\begin{array}{l}\text { Implemented } \mathrm{P} P \mathrm{P} / \mathrm{As} \text { from its SDMP that support } \\
\text { existing livelihood for the organizations such as } \\
\text { provision of capital and or materials and equipment. }\end{array}$ & $\begin{array}{l}1.00 \\
\mathrm{SA}\end{array}$ & 0.000 & $\begin{array}{l}1.19 \\
\text { SA }\end{array}$ & .402 & $\begin{array}{l}1.48 \\
\text { SA }\end{array}$ & .504 & $\begin{array}{c}2.20 \\
\mathrm{~A}\end{array}$ & .825 & $\begin{array}{c}1.80 \\
\mathrm{~A}\end{array}$ & .765 & $\begin{array}{c}1.85 \\
\mathrm{~A}\end{array}$ & .833 \\
\hline $\begin{array}{l}\text { The livelihood organizations hav } \\
\text { P/P/As implemented from the SD }\end{array}$ & $\begin{array}{l}1.38 \\
\text { SA }\end{array}$ & .490 & $\begin{array}{l}1.67 \\
\text { SA }\end{array}$ & .796 & $\begin{array}{c}2.37 \\
\mathrm{~A}\end{array}$ & .734 & $\begin{array}{c}1.85 \\
\mathrm{~A}\end{array}$ & .804 & $\begin{array}{l}1.66 \\
\text { SA }\end{array}$ & .568 & $\begin{array}{c}1.84 \\
\mathrm{~A}\end{array}$ & .782 \\
\hline \multicolumn{13}{|l|}{ Infrastructure Development } \\
\hline $\begin{array}{l}\text { The Company implemented } \mathrm{P} P / \mathrm{As} \text { from its SDMP to } \\
\text { support infrastructure projects in our community. }\end{array}$ & $\begin{array}{l}1.00 \\
\text { SA }\end{array}$ & 0.000 & $\begin{array}{l}1.00 \\
\text { SA }\end{array}$ & 0.000 & $\begin{array}{l}1.59 \\
\text { SA }\end{array}$ & .496 & $\begin{array}{l}1.53 \\
\mathrm{SA}\end{array}$ & .656 & $\begin{array}{c}1.82 \\
\mathrm{~A}\end{array}$ & .756 & $\begin{array}{l}1.48 \\
\text { SA }\end{array}$ & .632 \\
\hline $\begin{array}{l}\text { The community benefitted from the infrastructure } \mathrm{P} / \mathrm{P} / \mathrm{As} \\
\text { implemented from the SDMP of the Company. }\end{array}$ & $\begin{array}{l}1.00 \\
\text { SA }\end{array}$ & 0.000 & $\begin{array}{l}1.00 \\
\text { SA }\end{array}$ & 0.000 & $\begin{array}{l}1.56 \\
\text { SA }\end{array}$ & .744 & $\begin{array}{l}1.42 \\
\text { SA }\end{array}$ & .532 & $\begin{array}{l}1.36 \\
\text { SA }\end{array}$ & .718 & $\begin{array}{l}1.36 \\
\mathrm{SA}\end{array}$ & .572 \\
\hline \multicolumn{13}{|l|}{ Access to Education } \\
\hline $\begin{array}{l}\text { The Company implemented P/P/As from its SDMP to } \\
\text { support education programs }\end{array}$ & $\begin{array}{l}1.00 \\
\text { SA }\end{array}$ & 0.000 & $\begin{array}{l}1.00 \\
\text { SA }\end{array}$ & 0.000 & $\begin{array}{l}1.28 \\
\text { SA }\end{array}$ & .452 & $\begin{array}{l}1.42 \\
\text { SA }\end{array}$ & .532 & $\begin{array}{l}1.41 \\
\mathrm{SA}\end{array}$ & .497 & $\begin{array}{l}1.33 \\
\mathrm{SA}\end{array}$ & .492 \\
\hline $\begin{array}{l}\text { The educational system in our community improved out } \\
\text { of the PIPAs implemented coming from the SDMP of } \\
\text { the Company. }\end{array}$ & $\begin{array}{c}2.20 \\
\mathrm{~A}\end{array}$ & .726 & $\begin{array}{c}2.81 \\
D\end{array}$ & .680 & $\begin{array}{l}1.54 \\
\text { SA }\end{array}$ & .503 & $\begin{array}{l}1.44 \\
\text { SA }\end{array}$ & .534 & $\begin{array}{c}2.25 \\
\mathrm{~A}\end{array}$ & .781 & $\begin{array}{c}1.72 \\
\mathrm{~A}\end{array}$ & .728 \\
\hline \multicolumn{13}{|l|}{ Access to Health Programs } \\
\hline $\begin{array}{l}\text { The Company implemented } \mathrm{P} / \mathrm{P} / \mathrm{As} \text { from its SDMP to } \\
\text { support health programs for the community. }\end{array}$ & $\begin{array}{c}2.20 \\
\mathrm{~A}\end{array}$ & .726 & $\begin{array}{c}2.29 \\
\mathrm{~A}\end{array}$ & .463 & $\begin{array}{c}2.89 \\
D\end{array}$ & .965 & $\begin{array}{l}1.44 \\
\text { SA }\end{array}$ & .535 & $\begin{array}{c}1.84 \\
\mathrm{~A}\end{array}$ & .776 & $\begin{array}{c}1.84 \\
\mathrm{~A}\end{array}$ & .842 \\
\hline $\begin{array}{l}\text { In general, the community experienced improved health } \\
\text { conditions from the P/P/As implemented coming from } \\
\text { the SDMP of the Company. }\end{array}$ & $\begin{array}{c}2.73 \\
D\end{array}$ & .539 & $\begin{array}{c}2.43 \\
\mathrm{~A}\end{array}$ & .507 & $\begin{array}{l}3.52 \\
S D\end{array}$ & .504 & $\begin{array}{l}1.52 \\
\mathrm{SA}\end{array}$ & .572 & $\begin{array}{c}1.89 \\
\mathrm{~A}\end{array}$ & .538 & $\begin{array}{c}2.05 \\
\mathrm{~A}\end{array}$ & .915 \\
\hline \multicolumn{13}{|l|}{ Socio-cultural Values Protection } \\
\hline $\begin{array}{l}\text { The Company implemented } \mathrm{P} / \mathrm{P} / \mathrm{As} \text { that promote existing } \\
\text { socio-cultural values inherent to the community. }\end{array}$ & $\begin{array}{l}1.47 \\
\text { SA }\end{array}$ & .505 & $\begin{array}{l}1.29 \\
\text { SA }\end{array}$ & .463 & $\begin{array}{c}2.59 \\
\mathrm{D}\end{array}$ & .981 & $\begin{array}{l}1.63 \\
\text { SA }\end{array}$ & .557 & $\begin{array}{c}2.09 \\
\mathrm{~A}\end{array}$ & .291 & $\begin{array}{c}1.78 \\
\mathrm{~A}\end{array}$ & .712 \\
\hline $\begin{array}{l}\text { The community become more socially coherent and } \\
\text { culturally aware because of the PP/As implemented } \\
\text { through the SDMP of the Company. }\end{array}$ & $\begin{array}{c}1.73 \\
\mathrm{~A}\end{array}$ & .539 & $\begin{array}{l}1.43 \\
\mathrm{SA}\end{array}$ & .507 & $\begin{array}{c}2.19 \\
\mathrm{~A}\end{array}$ & 1.065 & $\begin{array}{l}1.51 \\
\mathrm{SA}\end{array}$ & .572 & $\begin{array}{c}2.05 \\
\mathrm{~A}\end{array}$ & .608 & $\begin{array}{l}1.69 \\
\text { SA }\end{array}$ & .711 \\
\hline
\end{tabular}

Table 1 shows the summary of the level of agreement of the respondents on the implementation of the Social Development and Management Programs of the Mining Companies. Results showed that the respondents strongly agree that "the company implemented P/P/As from its SDMP to support education programs" (Mean $=1.33, \mathrm{SD}=.492)$. Likewise, they strongly agree that "the community benefitted from the infrastructure P/P/AsP/P/A implemented from the SDMP of the Company $($ Mean $=1.36, \mathrm{SD}=.572)$. Generally, the respondents agreed the SDMP were implemented accordingly. 
Table 2: Summary of the Level of Agreement on the Sustainability of the Social Development and Management Programs of the Mining Companies in terms of:

\begin{tabular}{|c|c|c|c|c|c|c|c|c|c|c|c|c|}
\hline \multirow[t]{3}{*}{ A. Stakeholder Groups Relationship } & \multicolumn{2}{|c|}{ CAMP 3} & \multicolumn{2}{|c|}{ DIDIPIO } & \multicolumn{2}{|c|}{ MINUYAN } & \multicolumn{2}{|c|}{ SAN ROQUE } & \multicolumn{2}{|c|}{ MATICTIC } & \multicolumn{2}{|c|}{ Overall } \\
\hline & \multicolumn{2}{|c|}{$N=45$} & \multicolumn{2}{|c|}{$\mathrm{N}=21$} & \multicolumn{2}{|c|}{$N=54$} & \multicolumn{2}{|c|}{$\mathrm{N}=212$} & \multicolumn{2}{|c|}{$N=44$} & \multicolumn{2}{|c|}{$N=376$} \\
\hline & Mean & SD & Mean & SD & Mean & SD & Mean & SD & Mean & SD & Mean & SD \\
\hline \multicolumn{13}{|l|}{ 1. Before SDMP } \\
\hline $\begin{array}{l}\text { The Company identified stakeholder groups } \\
\text { located in the Mining Project. }\end{array}$ & $\begin{array}{c}2.18 \\
\mathrm{~A}\end{array}$ & .576 & $\begin{array}{c}1.76 \\
\mathrm{~A}\end{array}$ & .436 & $\begin{array}{c}1.83 \\
\mathrm{~A}\end{array}$ & .986 & $\begin{array}{c}1.82 \\
\mathrm{~A}\end{array}$ & .861 & $\begin{array}{c}2.32 \\
\mathrm{~A}\end{array}$ & .708 & $\begin{array}{c}1.92 \\
\mathrm{~A}\end{array}$ & .833 \\
\hline $\begin{array}{l}\text { There are social issues raised against the } \\
\text { Mining Project. }\end{array}$ & $\begin{array}{l}1.00 \\
\text { SA }\end{array}$ & .000 & $\begin{array}{c}1.52 \\
\mathrm{~S}\end{array}$ & .512 & $\begin{array}{l}1.00 \\
\text { SA }\end{array}$ & .000 & $\begin{array}{l}1.41 \\
\text { SA }\end{array}$ & .722 & $\begin{array}{l}1.45 \\
\text { SA }\end{array}$ & .504 & $\begin{array}{l}1.31 \\
\text { SA }\end{array}$ & .607 \\
\hline $\begin{array}{l}\text { The Company responded to the issues raised to } \\
\text { them. }\end{array}$ & $\begin{array}{l}1.38 \\
\text { SA }\end{array}$ & .576 & $\begin{array}{c}2.00 \\
\mathrm{~A}\end{array}$ & .000 & $\begin{array}{c}2.50 \\
\mathrm{D}\end{array}$ & 1.077 & $\begin{array}{c}2.04 \\
\mathrm{~A}\end{array}$ & .753 & $\begin{array}{c}2.59 \\
\mathrm{D}\end{array}$ & .497 & $\begin{array}{c}2.09 \\
\mathrm{~A}\end{array}$ & .818 \\
\hline $\begin{array}{l}\text { The stakeholder groups are satisfied with the } \\
\text { process. }\end{array}$ & $\begin{array}{c}2.71 \\
\mathrm{D}\end{array}$ & .458 & $\begin{array}{l}3.57 \\
\mathrm{SD}\end{array}$ & .598 & $\begin{array}{c}2.70 \\
\mathrm{D}\end{array}$ & .662 & $\begin{array}{c}2.46 \\
\mathrm{~A}\end{array}$ & .955 & $\begin{array}{c}2.68 \\
\mathrm{D}\end{array}$ & .601 & $\begin{array}{c}2.61 \\
\mathrm{D}\end{array}$ & .854 \\
\hline \multicolumn{13}{|l|}{ 2. SDMP Proceeding } \\
\hline $\begin{array}{l}\text { The stakeholder groups are properly informed } \\
\text { of the Company SDMP }\end{array}$ & $\begin{array}{c}2.73 \\
\mathrm{D}\end{array}$ & .447 & $\begin{array}{c}3.00 \\
\mathrm{D}\end{array}$ & .707 & $\begin{array}{c}3.13 \\
\mathrm{D}\end{array}$ & .912 & $\begin{array}{c}2.34 \\
\mathrm{~A}\end{array}$ & .790 & $\begin{array}{c}2.39 \\
\mathrm{~A}\end{array}$ & .754 & $\begin{array}{c}2.54 \\
\mathrm{D}\end{array}$ & .822 \\
\hline $\begin{array}{l}\text { The stakeholder groups are involved in the } \\
\text { development of the SDMP }\end{array}$ & $\begin{array}{c}1.80 \\
\mathrm{~A}\end{array}$ & .694 & $\begin{array}{c}3.24 \\
\mathrm{D}\end{array}$ & .768 & $\begin{array}{c}1.91 \\
\mathrm{~A}\end{array}$ & 1.051 & $\begin{array}{c}2.14 \\
\mathrm{~A}\end{array}$ & .921 & $\begin{array}{c}2.18 \\
\mathrm{~A}\end{array}$ & .756 & $\begin{array}{c}2.13 \\
\mathrm{~A}\end{array}$ & .936 \\
\hline $\begin{array}{l}\text { The stakeholder groups are satisfied with the } \\
\text { Company SDMP }\end{array}$ & $\begin{array}{c}2.18 \\
\mathrm{~A}\end{array}$ & .387 & $\begin{array}{c}2.86 \\
\mathrm{D}\end{array}$ & .727 & $\begin{array}{c}1.80 \\
\mathrm{~A}\end{array}$ & .855 & $\begin{array}{l}1.71 \\
\text { SA }\end{array}$ & .752 & $\begin{array}{c}2.43 \\
\mathrm{~A}\end{array}$ & .695 & $\begin{array}{c}1.93 \\
\mathrm{~A}\end{array}$ & .798 \\
\hline $\begin{array}{l}\text { There are major social issues raised against the } \\
\text { SDMP }\end{array}$ & $\begin{array}{l}1.00 \\
\text { SA }\end{array}$ & .000 & $\begin{array}{l}1.00 \\
\text { SA }\end{array}$ & 0.000 & $\begin{array}{c}1.96 \\
\mathrm{~A}\end{array}$ & .846 & $\begin{array}{c}2.30 \\
\mathrm{~A}\end{array}$ & 1.076 & $\begin{array}{c}1.77 \\
\mathrm{~A}\end{array}$ & .859 & $\begin{array}{c}1.96 \\
\mathrm{~A}\end{array}$ & 1.033 \\
\hline $\begin{array}{l}\text { The Company addressed the social issues raised } \\
\text { against the SDMP. }\end{array}$ & $\begin{array}{c}2.22 \\
\mathrm{~A}\end{array}$ & .704 & $\begin{array}{c}3.19 \\
\mathrm{D}\end{array}$ & .512 & $\begin{array}{c}2.31 \\
\mathrm{~A}\end{array}$ & .886 & $\begin{array}{c}2.02 \\
\mathrm{~A}\end{array}$ & .823 & $\begin{array}{c}2.32 \\
\mathrm{~A}\end{array}$ & .639 & $\begin{array}{c}2.19 \\
\mathrm{~A}\end{array}$ & .829 \\
\hline $\begin{array}{l}\text { The stakeholder groups are satisfied with the acti } \\
\text { taken by the Company }\end{array}$ & $\begin{array}{c}3.00 \\
\mathrm{D}\end{array}$ & 0.000 & $\begin{array}{c}3.19 \\
D\end{array}$ & .512 & $\begin{array}{c}2.54 \\
\mathrm{D}\end{array}$ & .693 & $\begin{array}{c}1.96 \\
\mathrm{~A}\end{array}$ & .793 & $\begin{array}{c}2.25 \\
\mathrm{~A}\end{array}$ & .751 & $\begin{array}{c}2.27 \\
\mathrm{~A}\end{array}$ & .823 \\
\hline
\end{tabular}

\begin{tabular}{|c|c|c|c|c|c|c|c|c|c|c|c|c|}
\hline \multirow[t]{3}{*}{ A. Stakeholder Groups Relationship } & \multicolumn{2}{|c|}{ CAMP 3} & \multicolumn{2}{|c|}{ DIDIPIO } & \multicolumn{2}{|c|}{ MINUYAN } & \multicolumn{2}{|c|}{ SAN ROQUE } & \multicolumn{2}{|c|}{ MATICTIC } & \multicolumn{2}{|c|}{ Overall } \\
\hline & \multicolumn{2}{|c|}{$\mathrm{N}=45$} & \multicolumn{2}{|c|}{$\mathrm{N}=\mathbf{2 1}$} & \multicolumn{2}{|c|}{$\mathrm{N}=54$} & \multicolumn{2}{|c|}{$\mathrm{N}=212$} & \multicolumn{2}{|c|}{$\mathrm{N}=44$} & \multicolumn{2}{|c|}{$\mathrm{N}=376$} \\
\hline & Mean & SD & Mean & SD & Mean & SD & Mean & SD & Mean & SD & Mean & SD \\
\hline \multicolumn{13}{|l|}{ 3. Company Capability } \\
\hline $\begin{array}{l}\text { The Company } 1.5 \% \text { budget for SDMP enough } \\
\text { to implement the Programs/Projects/Activities } \\
\text { for the host community }\end{array}$ & 2.18 & .576 & 1.76 & .436 & 1.83 & .986 & 1.82 & .861 & 2.32 & .708 & $\begin{array}{c}1.92 \\
\mathrm{~A}\end{array}$ & .833 \\
\hline $\begin{array}{l}\text { The Company have adequate staff to manage } \\
\text { the SDMP. }\end{array}$ & 1.00 & .000 & 1.52 & .512 & 1.00 & .000 & 1.41 & .722 & 1.45 & .504 & $\begin{array}{c}1.31 \\
\text { SA }\end{array}$ & .607 \\
\hline $\begin{array}{l}\text { The staff possess respectable professional and } \\
\text { educational background. }\end{array}$ & 1.38 & .576 & 2.00 & .000 & 2.50 & 1.077 & 2.04 & .753 & 2.59 & .497 & $\begin{array}{c}2.09 \\
\mathrm{~A}\end{array}$ & .818 \\
\hline $\begin{array}{l}\text { There are complete set of SDMP documents in } \\
\text { the Office. }\end{array}$ & 2.71 & .458 & 3.57 & .598 & 2.70 & .662 & 2.46 & .955 & 2.68 & .601 & $\begin{array}{c}2.61 \\
\mathrm{D}\end{array}$ & .854 \\
\hline $\begin{array}{l}\text { There is an established procedure for the } \\
\text { SDMP implementation }\end{array}$ & 2.73 & .447 & 3.00 & .707 & 3.13 & .912 & 2.34 & .790 & 2.39 & .754 & $\begin{array}{c}2.54 \\
\mathrm{D}\end{array}$ & .822 \\
\hline $\begin{array}{l}\text { There is an established financial procedure in } \\
\text { the processing of the } P / P / A s \text { of the SDMP. }\end{array}$ & 1.80 & .694 & 3.24 & .768 & 1.91 & 1.051 & 2.14 & .921 & 2.18 & .756 & $\begin{array}{c}2.13 \\
\mathrm{~A}\end{array}$ & .936 \\
\hline $\begin{array}{l}\text { There is an established monitoring system for } \\
\text { the } P / P / A s \text { of the SDMP. }\end{array}$ & 2.18 & .387 & 2.86 & .727 & 1.80 & .855 & 1.71 & .752 & 2.43 & .695 & $\begin{array}{c}1.93 \\
\mathrm{~A}\end{array}$ & .798 \\
\hline
\end{tabular}

Table 2 shows the Summary of the level of agreement on the sustainability of the Social Development and Management Programs of the Mining Companies in terms of Stakeholder Groups Relationship Before SDMP. Results showed that the respondents of the five Barangays were strongly agreed that "there are social issues raised against the mining project" (Mean = $1.31, \mathrm{SD}=.504$ ) but they disagreed on "the stakeholder groups are satisfied with the process" $($ Mean $=1.31, \mathrm{SD}=.504)$. 
In terms of Stakeholder Groups Relationship on SDMP Proceeding, results revealed that the respondents from the five Barangays agreed on the SDMP proceeding except on one item which is "the stakeholder groups are properly informed of the Company SDMP" (Mean $=2.54$, $\mathrm{SD}=.822$ ).

In terms of Company Capability, results revealed that the respondents strongly agreed that "the Company have adequate staff to manage the SDMP" (Mean $=1.31, \mathrm{SD}=.607)$ but they disagreed on two items, firstly, that "there are complete set of SDMP documents in the Office" (Mean $=2.61, \mathrm{SD}=.854$ ) and secondly, that "there is an established procedure for the SDMP implementation" Mean $=2.54, \mathrm{SD}=.822$ ).

Table 3: Summary of the Level of Agreement on the Sustainability of the Social Development and Management Programs of the Mining Companies in terms of:

\begin{tabular}{|c|c|c|c|c|c|c|c|c|c|c|c|c|}
\hline \multirow[t]{3}{*}{ B. Adherence to the Legal Requirements } & \multirow{2}{*}{\multicolumn{2}{|c|}{$\begin{array}{c}\mathrm{CAMP} 3 \\
\mathrm{~N}=45\end{array}$}} & \multirow{2}{*}{\multicolumn{2}{|c|}{$\begin{array}{c}\mathrm{DIDIPI0} \\
\mathrm{N}=2 \mathrm{l}\end{array}$}} & \multirow{2}{*}{\multicolumn{2}{|c|}{$\frac{\mathrm{N}=54}{\mathrm{MINUYAN}}$}} & \multirow{2}{*}{\multicolumn{2}{|c|}{$\frac{\mathrm{SAN}}{\mathrm{N}=212}$}} & \multirow{2}{*}{\multicolumn{2}{|c|}{\begin{tabular}{|c|} 
MATICTIC \\
$\mathrm{N}=44$
\end{tabular}}} & \multirow{2}{*}{\multicolumn{2}{|c|}{$\begin{array}{l}\text { Overall } \\
\mathrm{N}=376\end{array}$}} \\
\hline & & & & & & & & & & & & \\
\hline & Mean & SD & Mean & SD & Mean & SD & Mean & SD & Mean & SD & Mean & SD \\
\hline \multicolumn{13}{|l|}{ 1.P/P/A Development } \\
\hline $\begin{array}{l}\text { The Company based its budgetary allocation on the previous } \\
\text { year's Operating Cost as prescribed by Law. }\end{array}$ & 1.00 & .000 & 1.00 & .000 & 1.00 & .000 & 2.41 & .573 & 1.52 & .698 & 1.86 & .814 \\
\hline $\begin{array}{l}\text { The sectors of the host communities were consulted based on } \\
\text { their needs, interest and capacities. }\end{array}$ & 2.07 & .688 & 2.10 & .436 & 2.37 & .708 & 2.12 & .450 & 1.80 & .594 & $\begin{array}{c}2.11 \\
A\end{array}$ & .559 \\
\hline $\begin{array}{l}\text { The Company submitted complete documents as required by } \\
\text { the Law. }\end{array}$ & 1.71 & .626 & 1.43 & .507 & 2.76 & 1.06 & 2.33 & .553 & 2.59 & .497 & $\begin{array}{c}2.30 \\
\mathrm{~A}\end{array}$ & .738 \\
\hline $\begin{array}{l}\text { The Company submitted all the documentary requirements } \\
\text { on time. }\end{array}$ & 1.89 & .647 & 1.86 & .478 & 2.41 & .836 & 2.71 & .903 & 2.48 & .505 & $\begin{array}{c}2.49 \\
\mathrm{~A}\end{array}$ & .861 \\
\hline $\begin{array}{l}\text { The Company adhered to the required substance and form of } \\
\text { the documents submitted. }\end{array}$ & 2.20 & .757 & 1.52 & .512 & 2.78 & 1.18 & 2.40 & .718 & 2.48 & .505 & $\begin{array}{c}2.39 \\
\mathrm{~A}\end{array}$ & .815 \\
\hline $\begin{array}{l}\text { The Identified programs projects activities are based on the } \\
\text { community needs. }\end{array}$ & 2.89 & .885 & 2.76 & .700 & 2.76 & .989 & 2.34 & .918 & 2.48 & .731 & $\begin{array}{c}2.51 \\
D\end{array}$ & .915 \\
\hline $\begin{array}{l}\text { The identified programs/ projects/activities of } \\
\text { the SDMP produced general community interest. }\end{array}$ & 1.78 & .420 & 1.52 & .512 & 2.74 & 1.12 & 2.72 & .812 & 1.00 & 0.00 & $\begin{array}{c}2.34 \\
\mathrm{~A}\end{array}$ & .986 \\
\hline $\begin{array}{l}\text { The programs/projects/activities of the SDMP encouraged the } \\
\text { community involvement for its implementation. }\end{array}$ & 1.00 & .000 & 1.24 & .436 & 1.94 & .564 & 1.92 & .625 & 1.89 & .722 & $\begin{array}{c}1.77 \\
A\end{array}$ & .663 \\
\hline $\begin{array}{l}\text { The Company signed a Memorandum of Agreement } \\
\text { with the representative/s of the community and LGU } \\
\text { in conjunction to the approved 5-Year SDMP. }\end{array}$ & 2.24 & .484 & 1.00 & 0.00 & 1.78 & .538 & 1.92 & .634 & 1.52 & .505 & $\begin{array}{c}1.84 \\
\mathrm{~A}\end{array}$ & .632 \\
\hline $\begin{array}{l}\text { The Company provided a complete set of approved documents } \\
\text { its host and neighboring communities } \\
\text { and the LGU }\end{array}$ & 2.76 & .773 & 3.19 & .402 & 2.57 & .499 & 2.13 & .454 & 2.09 & .802 & $\begin{array}{c}2.32 \\
A\end{array}$ & .637 \\
\hline $\begin{array}{l}\text { The Company created, as part of its operations, a Community } \\
\text { Relations Office for SDMP implementation. }\end{array}$ & 1.00 & 0.00 & 1.00 & 0.00 & 1.00 & 0.00 & 2.07 & .502 & 3.00 & 0.00 & $\begin{array}{c}1.84 \\
\mathrm{~A}\end{array}$ & .744 \\
\hline
\end{tabular}




\begin{tabular}{|c|c|c|c|c|c|c|c|c|c|c|c|c|}
\hline \multirow{3}{*}{ B. Adherence to the Legal Requirements } & \multirow{2}{*}{\multicolumn{2}{|c|}{$\begin{array}{c}\text { CAMP } 3 \\
\mathrm{~N}=45\end{array}$}} & \multirow{2}{*}{\multicolumn{2}{|c|}{$\begin{array}{c}\text { DIDIPIO } \\
\mathrm{N}=\mathbf{2 1}\end{array}$}} & \multirow{2}{*}{\multicolumn{2}{|c|}{$\begin{array}{c}\text { MINUYAN } \\
\mathrm{N}=54\end{array}$}} & \multirow{2}{*}{\multicolumn{2}{|c|}{$\begin{array}{c}\text { SAN ROQUE } \\
\mathrm{N}=\mathbf{2 1 2}\end{array}$}} & \multirow{2}{*}{\multicolumn{2}{|c|}{$\begin{array}{c}\text { MATICTIC } \\
\mathrm{N}=\mathbf{4 4}\end{array}$}} & \multirow{2}{*}{\multicolumn{2}{|c|}{$\begin{array}{l}\text { Overall } \\
\mathrm{N}=376\end{array}$}} \\
\hline & & & & & & & & & & & & \\
\hline & Mean & SD & Mean & SD & Mean & SD & Mean & SD & Mean & SD & Mean & SD \\
\hline \multicolumn{13}{|l|}{ 2. Monitoring } \\
\hline $\begin{array}{l}\text { The monthly internal monitoring was } \\
\text { conducted together with the host community. }\end{array}$ & 2.56 & .841 & 3.05 & .498 & 2.35 & .649 & 2.67 & .539 & 2.43 & .728 & 2.60 & .637 \\
\hline $\begin{array}{l}\text { The quarterly monitoring activity was } \\
\text { conducted by the MGB-RO together with the } \\
\text { company and host community. }\end{array}$ & 2.73 & .539 & 3.29 & .561 & 3.02 & .598 & 2.69 & .529 & 2.59 & .658 & 2.77 & .583 \\
\hline $\begin{array}{l}\text { The annual audit was conducted by the MGB- } \\
\text { CO together with the Company and host } \\
\text { community. }\end{array}$ & 2.56 & .624 & 2.67 & .796 & 2.80 & .491 & 2.55 & .569 & 2.68 & .561 & 2.61 & .583 \\
\hline \multicolumn{13}{|l|}{ 3. Evaluation } \\
\hline $\begin{array}{l}\text { The Social Impact Assessment was conducted } \\
\text { by the company to their previous 5-Year } \\
\text { SDMP }\end{array}$ & 1.58 & .499 & 1.86 & .359 & 2.67 & .476 & 2.59 & .613 & 2.00 & .647 & 2.37 & .688 \\
\hline $\begin{array}{l}\text { The programs, projects/activities of the SDMP } \\
\text { contributed to the socio-economic development } \\
\text { of the community. }\end{array}$ & 1.00 & 0.000 & 1.00 & 0.000 & 1.00 & 0.000 & 2.33 & .594 & 1.00 & 0.000 & 1.75 & .795 \\
\hline $\begin{array}{l}\text { There is a necessity for the improvement of the } \\
\text { programs/projects/activities to serve the needs } \\
\text { of the communities. }\end{array}$ & 4.00 & 0.000 & 4.00 & 0.000 & 3.00 & 0.000 & 4.00 & 0.000 & 1.00 & 0.000 & 3.51 & .977 \\
\hline
\end{tabular}

Table 3 shows the Summary of the level of agreement on the sustainability of the Social Development and Management Programs of the Mining Companies in terms of Adherence to the Legal Requirements. Results showed that the respondents of the five Barangays strongly agree that "there are social issues raised against the mining project" $($ Mean $=1.31, \mathrm{SD}=.504)$ but they disagree on the items that "the stakeholder groups are satisfied with the process" $($ Mean $=1.31, \mathrm{SD}=.504)$.

Table 4: Summary of the Level of Agreement on the Sustainability of the Social Development and Management Programs of the Mining Companies in terms of:

\begin{tabular}{|c|c|c|c|c|c|c|c|c|c|c|c|c|}
\hline \multirow[t]{3}{*}{ C. Major Challenges of SDMP } & \multicolumn{2}{|c|}{ CAMP 3} & \multicolumn{2}{|c|}{ DIDIPIO } & \multicolumn{2}{|c|}{ MINUYAN } & \multicolumn{2}{|c|}{ SAN ROQUE } & \multicolumn{2}{|c|}{ MATICTIC } & \multicolumn{2}{|c|}{ Overall } \\
\hline & \multicolumn{2}{|c|}{$\mathrm{N}=45$} & \multicolumn{2}{|c|}{$\mathrm{N}=21$} & \multicolumn{2}{|c|}{$\mathrm{N}=\mathbf{5 4}$} & \multicolumn{2}{|c|}{$\mathrm{N}=212$} & \multicolumn{2}{|c|}{$\mathrm{N}=44$} & \multicolumn{2}{|c|}{$\mathrm{N}=\mathbf{3 7 6}$} \\
\hline & Mean & SD & Mean & SD & Mean & SD & Mean & SD & Mean & SD & Mean & SD \\
\hline Diverse Culture of Community under SDMP & & & & & & & & & & & & \\
\hline $\begin{array}{l}\text { There are differing levels of understanding on } \\
\text { general welfare or well-being of the local } \\
\text { community. }\end{array}$ & 1.00 & 0.000 & 1.00 & 0.000 & 1.74 & 1.013 & 1.94 & .838 & 1.00 & 0.000 & $\begin{array}{l}1.64 \\
\text { SA }\end{array}$ & .844 \\
\hline $\begin{array}{l}\text { I believe that these differing levels of } \\
\text { understanding on general welfare contribute to } \\
\text { the difficulty in the successful implementation } \\
\text { of the SDMP }\end{array}$ & 1.00 & 0.000 & 1.00 & 0.000 & 1.00 & 0.000 & 2.13 & 1.147 & 1.00 & 0.000 & $\begin{array}{l}1.64 \\
\text { SA }\end{array}$ & 1.026 \\
\hline $\begin{array}{l}\text { SDMP of the Company is for the general } \\
\text { welfare or well-being of the local communities }\end{array}$ & 1.00 & 0.000 & 1.00 & 0.000 & 1.00 & 0.000 & 2.12 & 1.000 & 1.55 & 697 & $\begin{array}{l}1.70 \\
\mathrm{SA}\end{array}$ & .937 \\
\hline $\begin{array}{l}\text { Undue Political Influence on SDMP within } \\
\text { LGU }\end{array}$ & & & & & & & & & & & & \\
\hline $\begin{array}{l}\text { Politics within the LGU somehow hampers } \\
\text { success of SDMP. }\end{array}$ & 1.00 & 0.000 & 1.00 & 0.000 & 1.00 & 0.000 & 2.19 & .610 & 1.00 & 0.000 & $\begin{array}{l}1.67 \\
\text { SA }\end{array}$ & .747 \\
\hline $\begin{array}{l}\text { Prioritization of } \mathrm{P} / \mathrm{P} / \mathrm{As} \text { is not properly } \\
\text { identified due to varying interests? }\end{array}$ & 1.00 & 0.000 & 1.00 & 0.000 & 1.00 & 0.000 & 1.78 & .833 & 2.50 & .699 & $\begin{array}{l}1.61 \\
\text { SA }\end{array}$ & .822 \\
\hline
\end{tabular}




\begin{tabular}{|c|c|c|c|c|c|c|c|c|c|c|c|c|}
\hline \multirow[t]{3}{*}{ D. Major Challenges of SDMP } & \multicolumn{2}{|c|}{ CAMP 3} & \multicolumn{2}{|c|}{ DIDIPIO } & \multicolumn{2}{|c|}{ MINUYAN } & \multicolumn{2}{|c|}{ SAN ROQUE } & \multicolumn{2}{|c|}{ MATICTIC } & \multicolumn{2}{|c|}{ Overall } \\
\hline & \multicolumn{2}{|c|}{$\mathrm{N}=45$} & \multicolumn{2}{|c|}{$\mathrm{N}=21$} & \multicolumn{2}{|c|}{$\mathrm{N}=54$} & \multicolumn{2}{|c|}{$\mathrm{N}=212$} & \multicolumn{2}{|c|}{$\mathrm{N}=44$} & \multicolumn{2}{|c|}{$\mathrm{N}=376$} \\
\hline & Mean & SD & Mean & SD & Mean & SD & Mean & SD & Mean & SD & Mean & SD \\
\hline $\begin{array}{l}\text { Weak Monitoring System from External } \\
\text { Agencies }\end{array}$ & & & & & & & & & & & & \\
\hline $\begin{array}{l}\text { There is an established monitoring system for } \\
\text { SDMP implementation. }\end{array}$ & 3.18 & .684 & 3.24 & .436 & 3.63 & 4.131 & 2.04 & .734 & 1.00 & 0.000 & $\begin{array}{c}2.35 \\
D\end{array}$ & 1.847 \\
\hline $\begin{array}{l}\text { There is weak monitoring system from external } \\
\text { agencies that affects the successful SDMP } \\
\text { implementation. }\end{array}$ & 1.47 & .505 & 1.90 & .768 & 1.35 & .894 & 1.54 & .711 & 1.00 & 0.000 & $\begin{array}{l}1.46 \\
\text { SA }\end{array}$ & .707 \\
\hline $\begin{array}{l}\text { The difficulty in correcting gaps in the } \\
\text { implementation of the P/P/A due to slow } \\
\text { submission of monitoring reports affect the } \\
\text { success of the SDMP. }\end{array}$ & 1.00 & 0.000 & 1.00 & 0.000 & 1.00 & 0.000 & 1.48 & .501 & 1.82 & .786 & $\begin{array}{l}1.36 \\
\text { SA }\end{array}$ & .534 \\
\hline $\begin{array}{l}\text { There is lack of coordination between the } \\
\text { monitoring agency and Company that hampers } \\
\text { the successful implementation of SDMP }\end{array}$ & 1.27 & .447 & 1.52 & .512 & 1.63 & .623 & 1.36 & .737 & 1.00 & 0.000 & $\begin{array}{l}1.35 \\
\text { SA }\end{array}$ & .653 \\
\hline $\begin{array}{l}\text { Do you believe that if the monitoring system is } \\
\text { solid, it can contribute to the successful SDMP } \\
\text { implementation? }\end{array}$ & 1.00 & 0.000 & 1.00 & 0.000 & 1.00 & 0.000 & 1.56 & .798 & 1.00 & 0.000 & $\begin{array}{l}1.31 \\
\text { SA }\end{array}$ & .659 \\
\hline
\end{tabular}

Table 4 shows the Summary of the level of agreement on the sustainability of the Social Development and Management Programs of the Mining Companies in terms of Major Challenges encountered by the company. Results showed that the respondents of the five Barangays strongly agree that "there are social issues raised against the mining project" (Mean $=1.31, \mathrm{SD}=.504)$ but they disagreed on "the stakeholder groups are satisfied with the process" $($ Mean $=1.31, \mathrm{SD}=.504)$.

\section{Conclusions}

Based on the results of the study, the following conclusions were drawn:

1. It can be concluded that the respondents strongly agree that "the company implemented P/P/As from its SDMP to support education programs." Likewise, they strongly agree that "the community benefitted from the infrastructure P/P/AsP/P/A implemented from the SDMP of the Company.

2. It is conclusive that the respondents strongly agreed that "the Company have adequate staff to manage the SDMP" but they disagreed on two items, firstly, that "there are complete set of SDMP documents in the Office" and secondly, that "there is an established procedure for the SDMP implementation."

3. The respondents of the five Barangays disagree on the items that "the stakeholder groups are satisfied with the process."

4. The respondents of the five Barangays strongly agree that "there are social issues raised against the mining project" but they disagreed on "the stakeholder groups are satisfied with the process."

5. Generally, the respondents agreed the SDMP were implemented accordingly. 


\section{References}

Dupuy, K. E. (2014). Community development requirements in mining laws. The Extractive Industries and Society, 1(2), 200-215. doi: 10.1016/j.exis.2014.04.007

Editor's Comments. (2004). Community Development Society. Journal, 34(2), i-ii. doi:10.1080/15575330409490109

Greenhill, et al., 2009. (n.d.). Investors are more likely to invest if they see that there are certain qualities and good behaviors to prove that their investments are secured. doi:10.1787/888933458242

HOLCIM MINING AND DEVELOPMENT CORPORATION. (2017, November 30). Contact Us [Web log post]. Retrieved from https://www.holcim.ph/contact-us Holcim Mining and Development Corporation. Retrieved from https://www.holcim.ph/news/latestreleases/latestrelease/article/holcim-philippineseducation-program-wins-regional-csr-award)

Holcim Philippines. (2018, April 3). About Us. Retrieved from https://www.holcim.ph/aboutus

Mines and Geosciences Bureau. (2018). Mining industry in the Philippines continue to meet all the needs of the present generation. Mining companies put CSR on top of business agenda. (2008). Mining companies put CSR on top of business agenda. Philippines.

OceanaGold Mining Corporation. (n.d.). Sustainability - OceanaGold. Retrieved from http://www.oceanagold.com/sustainability OceanaGold Mining Corporation. (n.d.). Vision \& Values - OceanaGold. Retrieved from https://www.oceanagold.com/aboutus/vision-values/

OCEANAGOLD. (n.d.). Event Registration. Retrieved from https://event.on24.com/eventRegistration/EventLobbyServlet?target=reg20.jsp\&referr er $=$ https $\% 3 \mathrm{~A} \% 2 \mathrm{~F} \% 2 \mathrm{Fwww}$.oceanagold.com\%2Finvestor-centre\%2Ffinancialresults\%2F\&eventid $=1785607 \&$ sessionid $=1 \& \mathrm{key}=\mathrm{E} 0306 \mathrm{E} 891 \mathrm{C} 1 \mathrm{CEB} 19 \mathrm{~A} 2 \mathrm{C} 8 \mathrm{~F} 1$

Philippine Extractive Industries Transparency Initiative. (2014). Extracting value in transparency, the third report. Philippines.

PHILEX MINING CORPORATION. (n.d.). VISION AND MISSION - PHILEX MINING CORPORATION. Retrieved from http://www.philexmining.com.ph/vision-andmission/ PHILEX Mining Corporation. Retrieved from http://www.philexmining.com.ph/2014/04/07/philex-mining-named-one-of-phs-bestin-csr-advocacy/)

Pimentel, B. S., Gonzalez, E. S., \& Barbosa, G. N. (2016). Decision-support models for sustainable mining networks: fundamentals and challenges. Journal of Cleaner Production, 112, 2145-2157. doi:10.1016/j.jclepro.2015.09.023

Republic Cement and Building Materials Incorporated, R. (n.d.). Corporate Social Responsibility [Web log post]. Retrieved from http://www.republiccement.com/ouradvocacies/corporate-social-responsibility

Republic Cement. (n.d.) About Us. Retrieved from https://republiccement.com/about/World Bank. (2012). Mining Community Development Agreements. Retrieved from http://siteresources.worldbank.org/INTOGMC/Resources/mining_community.pdf

The World Bank. (2012). Mining Community Development Agreements is a product of the World Bank Sustainable Energy_Oil, Gas, and Mining Unit (SEGOM).

Zvarivadza, T. (2018). Sustainability in the mining industry: An evaluation of the National Planning Commission's diagnostic overview. Resources Policy, 56, 70-77. doi: 10.1016/j.resourpol.2018.01.008 